\title{
Effectiveness of Bilateral and Multilateral Official Development Assistance on Economic Growth in CEMAC: An Expansion Variable Analysis Method
}

\author{
Adèle M. Ngo Bilong Amoa \\ Maroua University, Maroua, Cameroon \\ Email: adelebilong1@yahoo.fr
}

How to cite this paper: Amoa, A. M. N. B. (2020). Effectiveness of Bilateral and Multilateral Official Development Assistance on Economic Growth in CEMAC: An Expansion Variable Analysis Method. Theoretical Economics Letters, 10, 322-333. https://doi.org/10.4236/tel.2020.102022

Received: February 21, 2020

Accepted: April 20, 2020

Published: April 23, 2020

Copyright ( 2020 by author(s) and Scientific Research Publishing Inc. This work is licensed under the Creative Commons Attribution International License (CC BY 4.0).

http://creativecommons.org/licenses/by/4.0/

(c) (i) Open Access

\begin{abstract}
This study investigates the effectiveness of aid in Economic and Monetary Community of Central Africa (CEMAC) from 1978 to 2010. We use panel data model and the decomposition of Casetti and Jones to test the linkages between bilateral and multilateral Official Development Assistance (ODA) and economic growth. Four main conclusions were drawn: Firstly, the most prominent positive effects come from the interaction of aid and Foreign Direct Investment. Thus, the interaction of aid and FDI plays a significantly positive role in economic growth in CEMAC. This result assumes a form of complementarity between FDI and ODA flows in the subregion. Secondly, of the four external sources of financing of the economy, Foreign Direct Investment (FDI) does not play a positive role in the growth in CEMAC. Thirdly, Economic growth in the sub-region seems to be more dependent on savings and the trade balance. Fourtly, according to origin of aid, multilateral aid as well as aid from the Development Assistance Committee (DAC) or Emerging Countries explains economic growth in CEMAC but its direct effect on it is negative. We find that of the three aid packages, DAC, emerging or multilateral, the DAC subsidies contribute the least negatively to growth. Public aid explains economic growth in CEMAC, but its effect on economic growth is negative; a $1 \%$ increase in ODA would lead to a $3 \%$ drop in growth.
\end{abstract}

\section{Keywords}

Aid, Expansion Variable, Multilateral, Bilateral, CEMAC

\section{Introduction}

When a country or a region fails to generate sufficient domestic savings to finance 
its economic growth, it looks for funds from other countries: it is foreign funding. This foreign financing includes both private and public funds.

Private funds have four components: foreign direct investment, portfolio investment, commercial bank loans, and export credits. The former are carried out by non-residents, most often multinational firms in companies located in host countries. The control of the local company is assured totally or partially by the multinational firm. As for portfolio investment, it consists of acquisition, without any control over the management of bonds or shares of the host country by foreigners. Exporting firms, commercial banks and state-owned banks offer export credits to importing countries to promote sales by allowing them time to pay for their imports, which are often subject to market interest rates.

For the most part, public financing benefits from privileged conditions and is granted in the form of either grants or "preferential" loans with interest rates lower than those prevailing on international private capital markets with long repayment terms.

Official Development Assistance (ODA), better known as Foreign Development Aid can be subdivided into bilateral aid, granted directly by one country to another, multilateral aid, where international organizations such as United Nations, World Bank and Regional Development Banks receive funds that they give or lend to recepients developing country. According to the Development Assistance Committee (DAC), development aid is the sum of the contributions paid to the countries and territories listed in the list of beneficiaries established by the DAC or to multilateral institutions whose administration has for main objective to promote economic development and well-being in developing countries (CAD, 2005). It refers to all the financial aid provided for in the State budget and transferred to the developing countries. It is a voluntary action by an external actor to boost the development of a third country (developing country) or a part of the public budget of a State (developed country) dedicated to the financing of development cooperation programs in poor and middle-income countries. ODA includes loans and grants (non-counterpart financing) from the public sector when the loans have preferential terms relative to the market.

Thus, to be counted as ODA, an expense must satisfy four criteria:

- Be addressed to a developing country under DAC or deficiency to an international organization such as World Bank;

- Come compulsorily from public bodies (states, local authorities);

- Promote economic development and the improvement of living standards in the countries concerned;

- Take the form of grants or loans and include a minimum element of liberality (Charnoz \& Severino, 2007; Lechevallier \& Pacquement, 2007).

Aid effectiveness generally refers to its ability to boost economic growth in recipient countries.

The CEMAC countries, Cameroon, Congo, Gabon, Equatorial Guinea, Central African Republic and Chad have benefited from development aid for several 
decades. According to the Organization for Economic Cooperation and Development (OECD) statistics, aid to CEMAC increased from US \$1.4 billion to US $\$ 14$ billion between 1990 and 2010, an average annual increase of 9\%. Net ODA flows to CEMAC countries are made up of bilateral and multilateral aid. Bilateral aid comes from the Development Assistance Committee, which has currently thirty members. Among them, the largest donors are: the United States, the United Kingdom, Germany, France and Japan, the smallest being New Zealand, Luxembourg and Greece. The ODA granted by the DAC countries shows a contrasting development but the year 2010 is the one in which the CEMAC countries received the most aid in volume terms from the DAC, it amounted to more than 7 billion dollars while it hovered around two billion dollars until then.

With regard to aid from emerging countries, statistics from the United Nations Conference on Trade and Development (UNCTAD) show that the contribution of aid from emerging countries was large during the 1980s for almost all the countries of the sub region. The biggest donors are: China, Brazil, Russia and India.

Multilateral donors in CEMAC are: the European Union (EU), the World Bank/ IMF, the Food and Agriculture Organization of the United Nations (FAO), the United Nations Educational, Scientific and Cultural Organization (UNESCO), the African Capacity Building Fund (ACBF), the Intergovernmental Agency of la Francophonie (AIF), the African Development Bank (AfDB), the International Labor Office (ILO), the Commission United Nations Economic for Africa (CEA), Cooperation with the United Nations Environment Program (UNEP)...

\section{Literature}

In economic literature, the justification for aid stems from the neokeynesian theory that total output is proportional to the stock of capital in the economy. If we ignore capital depreciation, the variation or increase in the capital stock will be equal to that of savings and therefore to that of investment. Low savings in poor countries constrain investment and the rate of economic growth is therefore condemned to remain low. Thus, foreign funds of all kinds play the role of increasing domestic savings, in order to increase investment and consequently, to accelerate growth. Domar Evsey (1946), based on the example of differences in economic growth between the different American states, draws an important conclusion: while some economies are experiencing growth difficulties, it is because they are poor and have a low capital stock. In addition, developing economies have a low level of investment. Under these conditions, they cannot grow at the same rate as the others. External financing would therefore be an important element of the policy of economic growth. This argument is supported by many authors including Rosenstein-Rodan P. N. (1961), for whom there is a given threshold of capital per capita below which a country is condemned to remain poor. This is the threshold of the underdevelopment trap. International aid must enable beneficiary countries to boost their per capita stock of capital 
beyond this threshold (poverty trap threshold). This is how Rosenstein-Rodan P. N. (1961) proposes that we carry out a "big push" for all poor countries. On the other hand, in the literature on aid, there are two main currents critics of development aid policy, namely, liberals and Marxists.

Bauer P. T. (1984) is the pioneer, and often regarded as the leader of liberal-inspired critics of development aid policy. Friedman Milton (1958), Majewski John (1987), Berg Elliot (1996), Griffin Keith (1970) and Mosley P. and al. (1995) share the approach that development aid cannot promote economic growth in the South too. On the contrary, it sabotages it by distorting the rules of the market and economic liberalism. Financing by international aid has low or even negative returns. Very often, aid is used to create activities that the private sector has deliberately refused to fund because of low returns. Aid thus channels the resources of the recipient country towards unproductive or inefficient sectors and investments. Marxist-inspired authors such as Boccara (1973) consider external financing as an impoverishing factor. In this perspective, it is analyzed as a way to take advantage of the resources in poor beneficiary countries and especially as a means of internationalization of production mode and capitalist domination. Marxist-inspired criticisms of international aid have been gaining momentum in recent years with the development of a predominantly Frenchspeaking stream of thought, often referred to as "rejection of development", or "anti-development" current, in the name of their considerations, opposed to those of the IMF and the World Bank. The works of Latouche Serge (1998) and Rist Gilbert (2002) consider international aid as well as all development policies as serving primarily the cause of rich countries. For them, as a powerful channel through which industrialized countries continue to dominate developing countries, despite their political independence.

Finally, it becomes difficult to decide on the question of development aid in developing countries. Today, the conclusion is clear: the debate on the issue of aid is heavy; the question about its effectiveness in sub-Saharan Africa is well documented. Studies have been focusing around Asian countries (Mitra, Hossain, \& Hoss-ain, 2015) and many developing economies such as Cote d'Ivoire, Senegal... (Nowak-Lehmann et al., 2010; Nowak-Lehmann et al., 2012). Few empirical studies are available in Cameroon, Gabon, Central Africa Republic, Equatorial Guinea and Chad, countries which constitute CEMAC. The major focus of this study is to determine whether the different aids, namely, DAC aid, Emergency countries aid or multilateral aid are indifferently consistent in CEMAC.

\section{Econometric Model and Data}

\subsection{Model Specification}

The objective of this work is to assess and compare the effectiveness of ODA, specifically, DAC aid, Emergent countries aid and multilateral aid in CEMAC. We drew inspiration from the neoclassical growth model in an open economy 
derived from a Cobb-Douglas function. This model is widely used in the study of aid effectiveness. We will retain as explanatory variables of our model only the financing sources that are decisive for growth (Domar Evsey, 1946; Romer, 1986; King \& Ross, 1993). In general, almost all empirical studies (King \& Ross, 1993; Ross \& Sara, 1998; Beck et al., 2000) highlight a positive link between financial development and economic growth. Savings, for example, play a role in the economy of a country (Aghion \& Howitt, 2008; White, 1992; Lucas, 1988) show that foreign direct investment via positive externalities, could explain economic growth. Gross fixed capital formation, which represents investment, remains, according to the economic literature, the most important determinant of economic growth (Solow, 1956). The trade balance also remains a major determinant of economic growth (Chen, 2004). The size of the sample (6 countries only over 33 years) and the number of observations available in the various databases pose strong constraints in terms of degree of freedom and invite us to limit the number of variables present in the model.

The variable explained here is the GDP per capita. Based on the empirical literature, the econometric model is built upon the following equation:

$$
y_{t}=\alpha_{0}+\alpha_{1} f d i+\alpha_{2} X M_{t}+\alpha_{3} g f f f+\alpha_{4} S_{t}+\mu_{t}
$$

where $y_{t}$ is the natural logarithm of per capita GDP growth; both sources of external financing considered are expressed as a share of GDP: foreign direct investment $(f d i)$, and the trade balance $\left(X M_{t}\right)$. Finally, the savings rate $\left(S_{t}\right)$ and the gross fixed capital formation ( $\left.g f f_{t}\right)$ represent the fundamentals of the economy. Our study focuses on two-dimensional data: a chronological dimension and a spatial dimension. In our study, we will adopt the panel approach and apply the Variable Expansion (VE) method, described by Casetti E. and Jones J.P. III (1992) to measure the direct and indirect effect of each aid on economic growth in CEMAC.

\subsection{Econometric Methodology}

The basic model presented in Equation (1) is modified according to the method described by Casetti E. and Jones J. P. III (1992) in order to take into account the interactions that can exist between aid and other variables of the model. The underlying idea is that the relationship between aid and growth in GDP per capita is likely to vary according to the economic environment of each country, ie according to its savings rate, its exports and the FDI it receives (Casetti \& Jones, 1992). The coefficients of the initial model are then redefined to integrate aid in Equation (1):

$$
\begin{gathered}
y_{t}=\alpha_{0}+\alpha_{1} f d i+\alpha_{2} X M_{t}+\alpha_{3} g f c f+\alpha_{4} S_{t}+\mu_{t} \\
\alpha_{0}=\beta_{00}+\beta_{10} a_{t} \\
\alpha_{1}=\beta_{01}+\beta_{11} a_{t} \\
\alpha_{2}=\beta_{02}+\beta_{12} a_{t}
\end{gathered}
$$




$$
\begin{aligned}
& \alpha_{3}=\beta_{03}+\beta_{13} a_{t} \\
& \alpha_{4}=\beta_{04}+\beta_{14} a_{t}
\end{aligned}
$$

where $a_{t}$ is also expressed as a percentage of GDP. When we introduce these expansion equations into model (1), we obtain :

$$
\begin{aligned}
& y_{t}=\beta_{00}+\beta_{10} a_{t}+\alpha_{1} f d i+\alpha_{2} X M_{t}+\alpha_{3} g f c f_{t}+\alpha_{4} S_{t}+\mu_{t} \\
& y_{t}=\alpha_{0}+\beta_{01} f d i+\beta_{11} a_{t} f d i+\beta_{02} X M_{t}+\beta_{12} a_{t} X M_{t} \\
& +\beta_{03} g f c f_{t}+\beta_{13} a_{t} g f c f_{t}+\beta_{04} S_{t}+\beta_{14} a_{t} S_{t}+\mu_{t} \\
& y_{t}=\beta_{00}+\beta_{10} a_{t}+\beta_{01} f d i+\beta_{11} a_{t} f d i_{t}+\beta_{02} X M_{t}+\beta_{12} X M_{t} \\
& +\beta_{03} g f c f_{t}+\beta_{13} a_{t} g f c f+\beta_{04} S_{t}+\beta_{14} a_{t} S_{t}+\mu_{t}
\end{aligned}
$$

Equation (3) represents the direct effect of aid on GDP per capita growth. Equation (4) represents the indirect effect of aid on other variables in the model. Finally, Equation (5) gives the combined effect of aid on growth.

\subsection{Data}

The study uses annual data covering the period 1978-2010. Our sample is composed of 6 countries: Cameroon, Congo, Gabon, Equatorial Guinea, Central African Republic and Chad. All data series were obtained from the World Bank (2017). Variables used include real GDP used as a proxy for income (GDPt), Savings rate (St), Foreign Direct Investment (fdit), Commercial Balance, used as a proxy exports (XMt) and Gross Fixed Capital Formation (gfcft). All series were converted into natural logarithms so that they can be interpreted in growth terms after taking first difference and their respective coefficients represent elasticities. We used Stata 15 to conduct the econometric analysis.

\section{Empirical Results and Discussion}

Several tests relating to the panel data were carried out in order to better conduct the study. The specification test makes it possible to determine if the theoretical model is perfectly identical for all countries or if there are particular specificities to each country. Following Fisher's test, we can affirm the presence of specific model effects with a P-value equal to 0.000 . For the rest, according to the results of the Hausman test, we will use the fixed effects model. In order to be sure that the residual variance is the same for all individuals, we performed the BreuschPagan test, which indicates the lack of homogeneity with a P-value of less than $5 \%$. In addition, the chow test performed allowed us to check if the coefficient of a variable is different for two groups of data. In our model, the null hypothesis is not rejected, which supposes that there is no structural change. Since it is not possible to perform econometric applications on non-stationary series, unit root tests were therefore performed on the different variables in order to determine the degree of integration of the variables and to differentiate them as much as possible many times necessary to make them stationary. These are the tests of 
Levin A. and C. F. Lin (1992) and Im K. S., M. H. Pesaran and Y. Shin (1997). The series being all stationary, we can continue our estimations. If development assistance promotes economic growth in CEMAC, the coefficient of aid impact on economic growth will be positive and significantly different from zero.

The DAC aid statistical characteristics indicate that on average, Equatorial Guinea is the one which has received the most DAC aid and Gabon is the one which has received the least DAC aid during the period 1978-2010 amongst CEMAC countries (Table 1).

Table 2 above shows that Aid from Emergency countries has mostly been directed to Equatorial Guinea and is almost non present in Congo.

On average, DAC and Multilateral aid are the most important aid in CEMAC during the period 1978-2010 (Table 3). And as illustrated in Figure 1 below, during the period 1978-1990, total aid in GDP per capita was increasing. The year 1990 was the worst one in terms of Official Development Assistance but since 2000, the total aid amount in CEMAC is very low.

Table 1. Sum of DAC aid data statistical characteristics during the period 1978-2010.

\begin{tabular}{cccccccc}
\hline & Cameroon & Congo & Gabon & E. Guinea & CAR & Chad & CEMAC \\
\hline Mean & 3.74 & 4.99 & 1.17 & 8.66 & 6.99 & 6.43 & 5.33 \\
Std Dev & 3.87 & 4.78 & 0.86 & 10.04 & 2.28 & 3.00 & 5.55 \\
Variance & 14.98 & 22.88 & 0.74 & 100.75 & 5.22 & 9.02 & 30.82 \\
Skewness & 3.86 & 2.00 & 0.89 & 1.12 & 0.48 & 0.35 & 2.37 \\
Kurtosis & 19.33 & 6.76 & 3.16 & 3.07 & 3.18 & 1.78 & 10.13 \\
\hline
\end{tabular}

Table 2. Sum of emergency countries aid data statistical characteristics during the period 1978-2010.

\begin{tabular}{cccccccc}
\hline & Cameroon & Congo & Gabon & E. Guinea & CAR & Chad & CEMAC \\
\hline Mean & 0.41 & 0.006 & 0.03 & 0.57 & 0.11 & 0.36 & 0.18 \\
Std De & 0.63 & 0.009 & 0.06 & 0.89 & 0.15 & 0.77 & 0.52 \\
Variance & 0.004 & 0.000 & 0.003 & 0.79 & 0.02 & 0.59 & 0.27 \\
Skewness & 2.83 & 2.41 & 4.01 & 3.16 & 2.09 & 2.77 & 5.36 \\
Kurtosis & 10.45 & 9.25 & 20.75 & 15.43 & 8.22 & 11.78 & 39.92 \\
\hline
\end{tabular}

Table 3. Sum of multilateral aid data statistical characteristics during the period 1978-2010.

\begin{tabular}{cccccccc}
\hline & Cameroon & Congo & Gabon & E. Guinea & CAR & Chad & CEMAC \\
\hline Mean & 1.73 & 1.18 & 0.20 & 7.13 & 4.45 & 5.64 & 3.39 \\
Std Dev & 3.47 & 1.17 & 0.12 & 6.73 & 2.24 & 4.22 & 4.22 \\
Variance & 12.05 & 1.38 & 0.01 & 45.34 & 5.03 & 6.81 & 17.85 \\
Skewness & 5.01 & 2.68 & 0.63 & 0.24 & 0.55 & 0.00 & 1.75 \\
Kurtosis & 27.56 & 11.01 & 2.54 & 1.44 & 2.85 & 1.94 & 5.80 \\
\hline
\end{tabular}




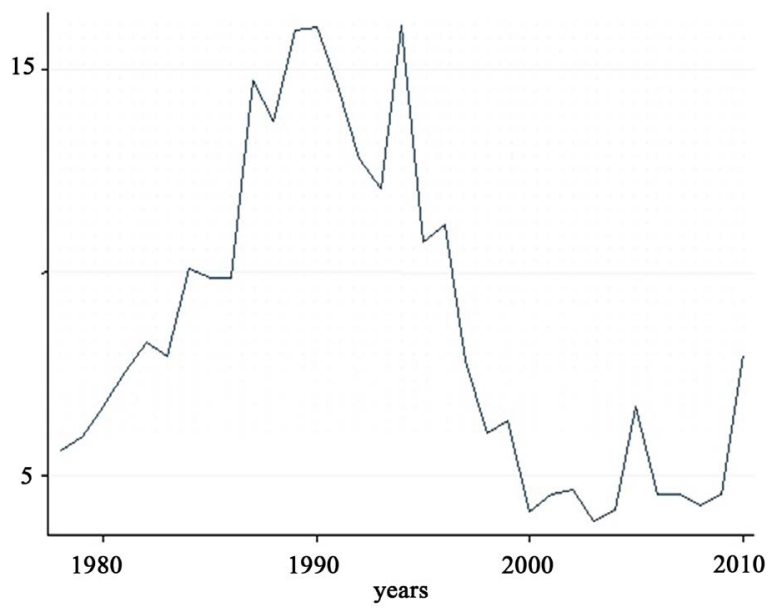

Figure 1. Total aid in GDP per capita in CEMAC.

The results of the estimation carried out as described above are summarized in the following tables (Table 4 and Table 5).

The results of the initial model estimates (Equation (1)), indicate that the funding sources chosen in our model explain growth in CEMAC. However, of the four external sources of finance, FDIs do not play a positive role in the growth of countries within the sub-region. The negative result of FDI, a variable representing external openness, is apparently disconcerting as it is seen as a means of accessing foreign technologies. But basically, this result is not very surprising given the limited inflow of FDIs into CEMAC. Economic growth within the sub-region seems to be more dependent on savings and the trade balance, which is explained by the fact that these countries are essentially exporters of raw materials.

Table 5, explaining direct effects of aid on economic growth shows that multilateral aid as well as DAC aid or Emerging Countries aid explain economic growth in CEMAC. But their direct effect on it is negative. But DAC aids contribute the least negatively to growth, probably because of its large volumes compared to Emerging Countries aid or multilateral aid. As in the initial model, the effect of FDI on growth is negative. The other sources, Gross Fixed Capital Formation, Savings, Trade Balance, have a rather significant positive direct effect on the growth in the sub-region.

Finally, public aid explains economic growth in CEMAC, but its effect on economic growth is negative whatever its origin; a $1 \%$ increase in ODA according to the model would lead to a $3 \%$ drop in growth. The results of indirect effects of aid on economic growth (Equation (4)) are reported in the following Table 6.

The table above shows that, in line with the results obtained in the initial model and in Equation (3), only FDI has a negative effect on economic growth; Gross Fixed Capital Formation, Trade Balance and Savings rate have a positive effect, but when FDI is crossed with development assistance variable, its effect on growth becomes positive. 
Table 4. Results of the initial model. Dependant variable: lnGDP/capita.

\begin{tabular}{ccccccc}
\hline Variables & Coefficient & Std. Error & $\mathrm{z}$ & $\mathrm{P}>\mathrm{z}$ & \multicolumn{2}{c}{ [95\% Conf. Interval] } \\
\hline Constant & 5.673 & 0.092 & 5.02 & 0.000 & 5.491 & 5.85 \\
fdi & $-0.008^{*}$ & 0.005 & -1.78 & 0.075 & -0.018 & 0.001 \\
gfcf & $1.800^{* * *}$ & 0.358 & 5.02 & 0.000 & 1.096 & 2.503 \\
Xm & $2.218^{* * *}$ & 0.217 & 10.19 & 0.000 & 1.792 & 2.645 \\
S & $2.385^{* * *}$ & 0.429 & 5.56 & 0.000 & 1.544 & 3.226 \\
R-sq = 0.716** & & Wald chi $(2)=440.42$, Prob $>$ chi2 $=0.000$ &
\end{tabular}

Note: $\mathrm{GDPt}=$ Economic growth, $\mathrm{St}=$ savings, $\mathrm{fdi}=$ foreign direct investment, $\mathrm{XM}=$ commercial balance, gfcft $=$ Gross Fixed Capital Formation. The asterisks ${ }^{*}{ }^{* *}$ and ${ }^{* * *}$ denote statistical significance at the $1 \%$, $5 \%$ and $10 \%$ levels, respectively.

Table 5. Direct effects of ODA of DAC, emerging countries and international organizations on economic growth in CEMAC. Dependant variable: $\operatorname{lnGDP} /$ capita.

\begin{tabular}{|c|c|c|c|c|c|c|c|c|}
\hline \multirow[t]{2}{*}{ Variables } & \multicolumn{2}{|c|}{ DAC Aid } & \multicolumn{2}{|c|}{$\begin{array}{c}\text { Emerging } \\
\text { Countries Aid }\end{array}$} & \multicolumn{2}{|c|}{$\begin{array}{c}\text { Multilateral } \\
\text { Aid }\end{array}$} & \multicolumn{2}{|c|}{$\begin{array}{c}\text { Total } \\
\text { Aid }\end{array}$} \\
\hline & Coefficient & P-Value & Coefficient & P-Value & Coefficient & P-Value & Coefficient & P-Value \\
\hline Constant & 5.850 & 0.000 & 5.679 & 0.000 & 5.913 & 0.000 & 5.980 & 0.000 \\
\hline DAC Aid & $-3.351^{\star * *}$ & 0.000 & & & & & & \\
\hline Emerg Aid & & & $-34.404^{\star \star \star}$ & 0.000 & & & & \\
\hline Multi Aid & & & & & $-6.688^{\star \star \star *}$ & 0.000 & & \\
\hline Total Aid & & & & & & & $-3.129^{\star * *}$ & 0.000 \\
\hline fdi & -0.007 & 0.140 & -0.005 & 0.306 & -0.007 & 0.124 & -0.006 & 0.199 \\
\hline gfcf & $1.256^{\star * *}$ & 0.002 & $1.0 .99^{\star * *}$ & 0.006 & $1.205^{\star * *}$ & 0.001 & $1.177^{\star \star *}$ & 0.002 \\
\hline $\mathrm{Xm}$ & $2.108^{\star * *}$ & 0.000 & $2.176^{\star * *}$ & 0.000 & $1.838^{\star * *}$ & 0.000 & $1.865^{\star * \star}$ & 0.000 \\
\hline $\mathrm{S}$ & 3.167 & 0.000 & $3.547^{\star * *}$ & & $3.234^{\star * *}$ & 0.000 & $3.176^{\star * *}$ & 0.000 \\
\hline R-sq & 0.658 & & 0.669 & & 0.678 & & 0.668 & \\
\hline Wald chi2 (4) & 511.70 & & 513.20 & & 581.78 & & 565.14 & \\
\hline Prob $>$ chi 2 & 0.000 & & 0.000 & & 0.000 & & 0.000 & \\
\hline
\end{tabular}

Note: $\mathrm{GDPt}=$ Economic growth, $\mathrm{St}=$ savings, $\mathrm{fdi}=$ foreign direct investment, $\mathrm{XM}=$ commercial balance, gfcft $=$ Gross Fix Capital Formation. The asterisks ${ }^{*},{ }^{*}$ and ${ }^{* *}$ denote statistical significance at the $1 \%, 5 \%$ and $10 \%$ levels, respectively.

Table 6. Indirect effects of ODA on economic growth in CEMAC. Dependant variable: $\operatorname{lnGDP} /$ capita.

\begin{tabular}{cccc}
\hline Variables & Coefficient & Std Error & P-Value \\
\hline Constant & 5.705 & 0.090 & 0.000 \\
fdi & $-0.017^{* *}$ & 0.006 & 0.010 \\
fdi x aid & $0.113^{*}$ & 0.057 & 0.051 \\
gfcf & $1.326^{* *}$ & 0.497 & 0.008 \\
gfff $x$ aid & -2.553 & 5.818 & 0.661 \\
\hline
\end{tabular}


Continued

\begin{tabular}{cccc}
\hline XM & $2.144^{* * *}$ & 0.317 & 0.000 \\
XM x aid & -3.797 & 2.963 & 0.200 \\
S & $4.024^{* * *}$ & 0.542 & 0.000 \\
S x aid & $-15.07^{* * *}$ & 4.805 & 0.002 \\
R-sq & 0.687 & & \\
Wald chi2 (4) & 606.85 & & \\
Prob $>$ chi2 & 0.000 & & \\
\hline
\end{tabular}

Note: $\mathrm{GDPt}=$ Economic growth, $\mathrm{St}=$ savings, fdi $=$ foreign direct investment, $\mathrm{XM}=$ commercial balance, gfcft $=$ Gross Fixed Capital Formation. The asterisks ${ }^{*},{ }^{* *}$ and ${ }^{* * *}$ denote statistical significance at the $1 \%$, $5 \%$ and $10 \%$ levels, respectively.

Thus, the interaction of aid and FDI plays a significantly positive role in growth in CEMAC. This result assumes a form of complementarity between FDI and ODA flows in the sub-region. The respective negative effects of ODA and FDI are therefore amortized when we cross these two variables.

\section{Conclusion and Policy Recommendations}

The question of the effectiveness of aid is not unanimous. For some, aid is an impediment to economic growth, for others, it helps to increase the economic growth of the recipient countries. Through a neoclassical model and the decomposition of Casetti E. and Jones J. P. III (1992) based on the expansion variable method, we studied the impact of aid on economic growth in CEMAC sub-region. This impact can be direct or via other sources of funding. Four main conclusions were drawn: Firstly, each funding source selected in our model, explains the economic growth in CEMAC. However, of the four external sources of financing of the economy, FDI does not play a positive role in the growth of the sub-region. This result can be translated by the limited inflows of FDI in CEMAC. Secondly, economic growth in the sub-region seems to be more dependent on savings and the trade balance, which is explained by the fact that these countries are essentially exporters of raw materials. Thirdly, regarding the direct effect of ODA on economic growth, we can conclude that Multilateral aid as well as aid from DAC or emerging countries explains economic growth in CEMAC. But their direct effect on it is negative. It can be noted that of the three aid package, DAC aid contributes the least negatively to growth, probably because of their large volumes compared to others. Public aid accounts for economic growth in CEMAC, but its effect on economic growth is negative; a $1 \%$ increase in ODA would lead, according to the model, to a 3\% drop in growth. Fourthly, when FDI is crossed with development aid, its effect on growth becomes positive. Thus, the interaction of aid and FDI plays a significantly positive role in economic growth in CEMAC. This result assumes a form of complementarity between FDI and ODA flows in the subregion. The respective negative effects of ODA and FDI are therefore amortized when we cross these two va- 
riables. Finally, it appears that development aid policies must be accompanied by policies to encourage FDI. CEMAC countries should therefore not raise barriers to ODA but at the same time promote FDI inflows to benefit from increased economic growth.

\section{Conflicts of Interest}

The authors declare no conflicts of interest regarding the publication of this paper.

\section{References}

Aghion, P., \& Howitt, P. (2008). The Economics of Growth. Cambridge, MA: MIT Press.

Bauer, P. T. (1984). Reality and Rhetoric: Studies in the Economics of Development (p. 52). Cambridge, MA: Harvard University Press.

Beck, T., Levine, R., \& Loayza, N. (2000). Finance and the Sources of Growth. Journal of Financial Economics, 58, 261-300.

Boccara, P. (1973). Études sur le capitalisme monopoliste d'État, sa crise et son issue, Éditions sociales (p. 226). Reprise d'un article d'Economie et Politique de déc 1969.

Casetti, E., \& Jones, J. P. III (1992). Applications of the Expansion Method. Londres: Routledge. https://doi.org/10.4324/9780203405383

Charnoz, O., \& Severino, J.-M. (2007). The Official Development Assistance. La Découverte.

Chen, N. (2004). Intra-National versus International Trade in the European Union: Why Do National Borders Matter? Journal of International Economics, 63, 93-118. https://doi.org/10.1016/S0022-1996(03)00042-4

Comité d'aide au développement CAD (2005). La gestion de l'aide: Pratiques des pays membres du CAD. Paris: OCDE.

Elliot, B. (1996). Dilemmas in Donor Aid Strategies. Mimeo, Workshop of External Resources for Development, Netherlands Economic Institute.

Evsey, D. (1946). Capital Expansion, Rate of Growth, and Employment. Econometrica, 14, 137-147. https://doi.org/10.2307/1905364

Gilbert, R. (2002). The History of Development: From Western Origins to Global Faith. New Delhi: Academic Foundation.

Im, K. S., Pesaran, M. H., \& Shin, Y. (1997). Testing for Unit Roots in Heterogeneous Panels. Cambridge: Department of Applied Economics, University of Cambridge.

Keith, G. (1970). Foreign Capital, Domestic Savings and Economic Development. Bulletin of the Oxford University Institute of Economics and Statistics, 32, 99-112. https://doi.org/10.1111/j.1468-0084.1970.mp32002002.x

King, R. G., \& Ross, L. (1993). Finance, Entrpreneurship and Growth. Journal of Monetary Economics, 32, 513-542. https://doi.org/10.1016/0304-3932(93)90028-E

Lechevallier, A., Moreau, J., \& Pacquement, F. (2007). Mieux gérer la mondialisation? L'aide publique au développement, Paris: ellipses.

Levin, A., \& Lin, C. F. (1992). Unit Root Test in Panel Data: Asymptotic and Finite-Sample Properties. Discussion Paper 92-93, San Diego, CA: Department of Economics, University of California.

Lucas, R. E. (1988). On the Mechanics of Economix Development. Journal of Monetary Economics, 22, 3-42. https://doi.org/10.1016/0304-3932(88)90168-7 
Majewski, J. (1987). Third World Development Foreign Aid or Free Trade (Vol. 37, No. 7). The Freeman, Foundation for Economic Education, Inc.

Milton, F. (1958). Foreign Economic Aid. Yale Review, 47, 501-516.

Mitra, R., Hossain, M. S., \& Hossain, M. I. (2015). Aid and Per-Capita Economic Growth in Asia: A Panel Cointegration Test. Economics Bulletin, 35, 1693-1699.

Mosley, P., Harrigan, J., \& Toye, J. (1995). Aid and Power (Vol. 1, 2). London: Routledge.

Nowak-Lehmann, D., Martínez-Zarzoso, I., Herzer, D., Klasen, S., \& Dreher, A. (2010). Foreign Aid and Its Effect on Per-Capita Income (Growth) in Recipient Countries: Pitfalls and Findings from a Time Series Perspective.

Nowak-Lehmann, F., Dreher, A., Herzer, D., Klasen, S., \& Martínez-Zarzoso, I. (2012). Does Foreign Aid Really Raise per Capita Income? A Time Series Perspective. Canadian Journal of Economics/Revue canadienne d'économique, 45, 288-313. https://doi.org/10.1111/j.1540-5982.2011.01696.x

Romer, P. M. (1986). Increasing Returns and Long Run Growth. Journal of Political Economy, 94, 1002-1037. https://doi.org/10.1086/261420

Rosenstein-Rodan, P. N. (1961). Notes on the Theory of the Big Push. In Ellis, \& Wallich (Eds.), Economic of Development for Latin America (pp. 57-81). New York: Saint-Martin's Press. https://doi.org/10.1007/978-1-349-08449-4 3

Ross, L., \& Sara, Z. (1998). Capital Control Liberalization and Stock Market Development. World Development, 26, 1169-1183. https://doi.org/10.1016/S0305-750X(98)00046-1

Serge, L. (1998). L'autre Afrique. Paris: Albin Michel.

Solow, R. M. (1956). A Contribution to the Theory of Economics Growth. Quarterly Journal of Economics, 70, 65-94. https://doi.org/10.2307/1884513

The World Bank (2017). World Development Indicators Data. https://data.worldbank.org/data-catalog/world-development-indicators

White, H. (1992). What Do We Know about Aid's Macroeconomic Impact? An Overview of the Aid Effectiveness Debate. Journal of International Development, 4, 121-137. https://doi.org/10.1002/jid.3380040203 